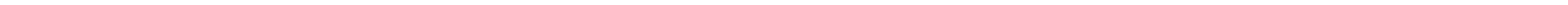


The Research School of Pacific and Asian Studies (RSPAS), a part of the ANU College of Asia and the Pacific at The Australian National University, is home to The Indonesia Project, a major international centre, which supports research activities on the Indonesian economy and society. Established in 1965 in the School's Division of Economics, the Project is well known and respected in Indonesia and in other places where Indonesia attracts serious scholarly and official interest. Funded by the ANU and the Australian Agency for International Development (AusAID), the Indonesia Project monitors and analyses recent economic developments in Indonesia; informs Australian governments, business and the wider community about those developments and about future prospects: stimulates research on the Indonesian economy; and publishes the respected Bulletin of Indonesian Economic Studies.

The School's Department of Political and Social Change (PSC) focuses on domestic politics, social processes and state-society relationships in Asia and the Pacific, and has a long-established interest in Indonesia.

Together with PSC and RSPAS, the Project holds the annual Indonesia Update conference, which offers an overview of recent economic and political developments and devotes attention to a significant theme in Indonesia's development. The Project's Bulletin of Indonesian Economic Studies publishes the economic and political overviews, while the proceedings related to the theme of the conference are published in the Indonesia Update Series.

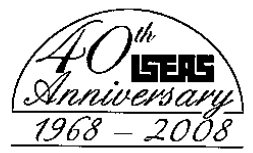

The Institute of Southeast Asian Studies (ISEAS) was established as an autonomous organization in 1968. It is a regional centre dedicated to the study of socio-political, security and economic trends and developments in Southeast Asia and its wider geostrategic and economic environment. The Institute's research programmes are the Regional Economic Studies (RES, including ASEAN and APEC), Regional Strategic and Political Studies (RSPS), and Regional Social and Cultural Studies (RSCS).

ISEAS Publishing, an established academic press, has issued almost 2,000 books and journals. It is the largest scholarly publisher of research about Southeast Asia from within the region. ISEAS Publishing works with many other academic and trade publishers and distributors to disseminate important research and analyses from and about Southeast Asia to the rest of the world.

\section{Expressing Islam Religious Life and Politics in Indonesia}

\author{
EDITED BY \\ Greg Fealy and Sally White
}

L7]:

Institute of Southeast Asian Studies Singapore 
First published in Singapore in 2008 by

ISEAS Publishing

Institute of Southeast Asian Studies

30 Heng Mui Keng Terrace

Pasir Panjang

Singapore 119614

E-mail: publish@iseas.edu.sg

http://bookshop.iseas.edu.sg

All rights reserved. No part of this publication may be reproduced, translated, stored in a retrieval system, or transmitted in any form or by any means, electronic, mechanical, photocopying, recording or otherwise, without the prior permission of the Institute of Southeast Asian Studies.

(C) 2008 Institute of Southeast Asian Studies, Singapore

The responsibility for facts and opinions in this publication rests exclusively with the authors and their interpretations do not necessarily reflect the views or the policy of the Institute or its supporters.

\section{ISEAS Library Cataloguing-in-Publication Data}

Expressing Islam : religious life and politics in Indonesia / edited by Greg Fealy and Sally White.

Based on the annual Indonesia Update Conference held at the Australian National University in 2007.

1. Islam-Indonesia--Congresses.

2. Islam and politics-Indonesia-Congresses.

3. Islam-Economic aspects-Indonesia - Congresses.

I. Fealy, Greg, 1957-

II. White, Sally, 1967-.

III. Indonesia Update Conference (2007: Canberra, Australia) DS644.4 I41 2007 2008

ISBN 978-981-230-850-4 (soft cover)

ISBN 978-981-230-851-1 (hard cover)

ISBN 978-981-230-852-8 (PDF)

Edited and typeset by Beth Thomson, Japan Online, Canberra

Indexed by Angela Grant, Sydney

Printed in Singapore by Seng Lee Press Pte Ltd

\section{CONTENTS}

List of Figures and Tables

List of Contributors

Acknowledgments

Glossary

vii

1 Introduction

Greg Fealy and Sally White

\section{PART I EXPRESSING PERSONAL PIETY}

2 Consuming Islam: Commodified Religion and Aspirational Pietism in Contemporary Indonesia Greg Fealy

3 Modulations of Active Piety: Professors and Televangelists as Promoters of Indonesian 'Sufisme' Julia Day Howell

4 Throwing Money at the Holy Door: Commercial Aspects of Popular Pilgrimage in Java George Quinn

5 'Spiritual Meal' or Ongoing Project? The Dilemma of Dakwah Oratory

Julian Millie

6 Marketing Morality: The Rise, Fall and Rebranding of $\mathrm{Aa}$ Gym James B. Hoesterey 


\section{PART II POLITICAL, SOCIAL AND LEGAL EXPRESSIONS OF ISLAM}

7 Religion, Politics and Social Dynamics in Java:

Historical and Contemporary Rhymes M.C. Ricklefs

8 Islam and Gender in Contemporary Indonesia: Public Discourses on Duties, Rights and Morality Sally White and Maria Ulfah Anshor

\section{FIGURES AND TABLES}

9 Online Fatwa in Indonesia: From Fatwa Shopping to Googling a Kiai Nadirsyah Hosen

10 Regional Sharia Regulations in Indonesia: Anomaly or Symptom? Robin Bush

11 'As Long as It's Halal': Islamic Preman in JakartaIan Douglas Wilson

12 Indonesian Terrorism: From Jihad to Dakwah? Ken Ward

\section{PART III THE ISLAMIC ECONOMY}

13 The Development of Islamic Banking in the Post-crisis Indonesian Economy Umar Juoro

14 Islamic Microfinance Initiatives to Enhance Small and Medium-sized Enterprises Muhammad Syafii Antonio

15 Community Development through Islamic Microfinance: Serving the Financial Needs of the Poor in a Viable Way Minako Sakai

Index

\section{FIGURES}

4.1 The Rise in Visitor Numbers to Major Sites of Islamic Pilgrimage in East Java

10.1 Religion-influenced Regional Regulations by Type of Regulation

10.2 Islam-related Regional Regulations by Content of Regulation

10.3 Religion-influenced Regional Regulations Issued Each Year, 1999-2007

10.4 Direct Local Election Results by Type of Political Party

13.1 Sharia Bank Assets as a Share of Total Bank Assets

13.2 Types of Contracts in the Islamic Economy

14.1 Linkages between Islamic Microfinance Institutions

\section{TABLES}

13.1 Islamic Bank Offices in Indonesia, 2007

13.2 Types of Contracts in the Islamic Economy

13.3 Balance Sheet of a Typical Islamic Bank

14.1 Categorisation of Small and Micro Financial Institutions in Indonesia

14.2 Islamic Banks and Finance Companies by Size of Capital and Credit Limit

14.3 Rural Banks and the Microfinance Units of Commercial Banks

14.4 Islamic Commercial Banks, Banking Units and Rural Banks in Indonesia, 2007

15.1 The Savings Products of BMT Al Kariim 
Kull, Ann (2005), Piety and Politics: Nurcholish Madjid and His Interpretation of Islam in Modern Indonesia, Lund Studies in History of Religions 21, Almqvist \& Wiksell International, Stockholm

Mujtaba, Achmad Nawawi (ed.) (2004), Menggapai Kenikmatan Zikir: Fenomena Muhammad Arifin Ilham dan Majelis Zikir Az-Zikra [Attaining the Gifts of Zikir: Muhammad Arifin Iham dan Majelis Zikir Az-Zikra [Attaining the Gifts of Zikir: Mizan, Jakarta.

Muzzaki, Akh (2007), 'Islam as Symbolic Commodity: Transmitting and Consuming Islam through Public Sermon in Indonesia', in P. Kitiarsa (ed.), Religiou Commodifications in Asia: Marketing Gods, Routledge, London, pp. 205-19. idwan, M. Deden (2002), 'Neo-Tarekat Aa Gym' [Aa Gym's Neo-Tarekat], Gatra, 3 August, p. 34

Satori, Syaefullah M. (2003), Akhi, Haruskah Manghujat Aa? Jawaban Buku 'Rapot Merah Aa Gym' [Akhi, Do You Have to Slander Aa? An Answer to the Book 'Rapot Merah Aa Gym'], Pustaka Medina, Jakarta.

Sitathan, Tony (2004), 'Preaching Islam Britney Style', Asia Times Online, 23 March, available at <http://www.atimes.com/atimes/Southeast_Asia/FC24Ae02. html>.

Syadzily, Tb. Ace Hasan (2005), Arifin Ilham, Dai Kota Penabur Kedamaian Jiwa [Arifin Ilham, the City Preacher Who Spreads Spiritual Tranquillity], Hikmah, Jakarta.

van Bruinesen, (1995), Kitab Kuning, Pesantren dan Tarekat [Kitab Kuning, Traditionalist Islamic Schools and Sufi Orders], Mizan, Bandung.

Zulkarnain, Tengku (2003), Salah Faham, Penyakit Umat Islam Masa Kini, Jawaban atas Buku Rapot Merah Aa Gym [Misunderstanding, the Sickness of the Islamic Community Today: A Rejoinder to the Book'Aa Gym's Failing Report Card'], Yayasan Al-Hakim, Jakarta.

\title{
4 THROWING MONEY AT THE HOLY DOOR: COMMERCIAL ASPECTS OF POPULAR PILGRIMAGE IN JAVA
}

\author{
George Quinn
}

Some 100 kilometres west of Jakarta, not far from Old Banten, stands the tomb of Sheik Muhammad Sholeh, an early preacher of Islam in the region. The tomb is at the summit of Gunung Santri, a tree-clad hill overlooking the rapidly developing harbour town of Bojonegara. Gunung Santri is a modestly popular place of pilgrimage for Indonesian Muslims. As pilgrims approach the saint's tomb, and even inside the mausoleum itself, they have to regotiate a series of alms boxes. Slipping money into the slot on an alms box, or giving something to a tomb custodian (kuncen or juru kunci), brings merit to the pilgrim and an income to the local community. But many pilgrims, especially poor ones, face a problem. There are so many alms boxes, and so many less than subtle invitations to make a donation, that to relinquish a banknote at each alms box-even the smallest denomination banknote-is more than many can afford.

Fortunately there is a convenient solution. On the path that winds up the hill to the sheik's tomb, dozens of rickety stalls feed off the passing flow of visitors. Among them is a microscopic money-changing operation - an amoebic 'bank'. Standing beside a rough wooden table two women offer cash-strapped pilgrims a simple but essential financial service. They replace banknotes with coins, taking a 20 per cent commission on each transaction. If a pilgrim lays a Rp 1,000 banknote on the table (the smallest denomination of Indonesia's banknotes, currently worth about ten US cents), he or she receives back a pile of eight Rp 100 coins. These go one by one into alms boxes or into the hands of tomb staff, buying merit for the pilgrim, saving them money, and generating a tiny but valuable income for the women of the 'single-cell' bank. 


\section{THE GROWING POPULARITY OF LOCAL PILGRIMAGE}

Money and pilgrimage go together. In fact, it is the central argument of this chapter that not only is pilgrimage an increasingly significant component of the domestic travel economy in Java, but commercial transactions in the marketplace of pilgrimage are also metaphorical actions that parallel devotional ritual and illuminate the relationship between believer and God.

Over the last two decades there has been an explosion in the number of Indonesian Muslims undertaking the haij pilgrimage to the Holy Land in Saudi Arabia, though for the moment the number is capped by the Saudi government at 205,000 a year. ${ }^{1}$ In tandem with this, there has also been a remarkable leap in the number of Muslims making visits to local places of pilgrimage in Java and Madura. There are well over 100 significant sites of Islamic pilgrimage across the two islands, ranging from the mausoleums of Java's renowned Nine Saints (Wali Songo) through the tombs of lesser saints, revered Muslim clerics, Muslim monarchs and local officials, to the graves of powerful women and the founding fathers of Islamic communities.

Evidence of the increase in pilgrim numbers is mostly anecdotal; reliable statistics that permit comparison of numbers over extended periods are difficult to come by. To my knowledge the best - though still not comprehensive - account of visitor numbers to pilgrimage sites appears in a report by Armstrong (2006). The report confines itself to sites administered by the Archaeological Service (Dinas Purbakala) of East Java. It records a startling rise in the number of people visiting Islamic gravesites over the last two decades. Armstrong (2006: 64) finds that between 1988 and 2005 visits to such sites rose by 873 per cent, from a total of less than half a million for the province in 1988 to three and a half million in 2005 (see Figure 4.1). ${ }^{2}$

The report also records figures for visits to other kinds of 'archaeological' sites, most notably pre-Islamic temple monuments (candi), museums and caves. Interest in most of these sites has declined significantly by comparison with interest in Islamic gravesites. In 1988 only 49 per cent of visits to all categories of archaeological sites administered by the East Java Archaeological Service were to Islamic gravesites, but by 2005 this had risen to 89 per cent (Armstrong 2006: 6).

1 'Kuota Haji Mungkin Naik, Ongkos Tidak' [The Quota for Pilgrims May Rise, but the Cost Will Not], Tempo Interaktif Ekonomi Bisnis, 18 May 2005.

2 I am grateful to David Armstrong for providing the data on which Figure 4.1 is based. Figure 4.1 The Rise in Visitor Numbers to Major Sites of Islamic Pilgrimage
in East Java (in millions)

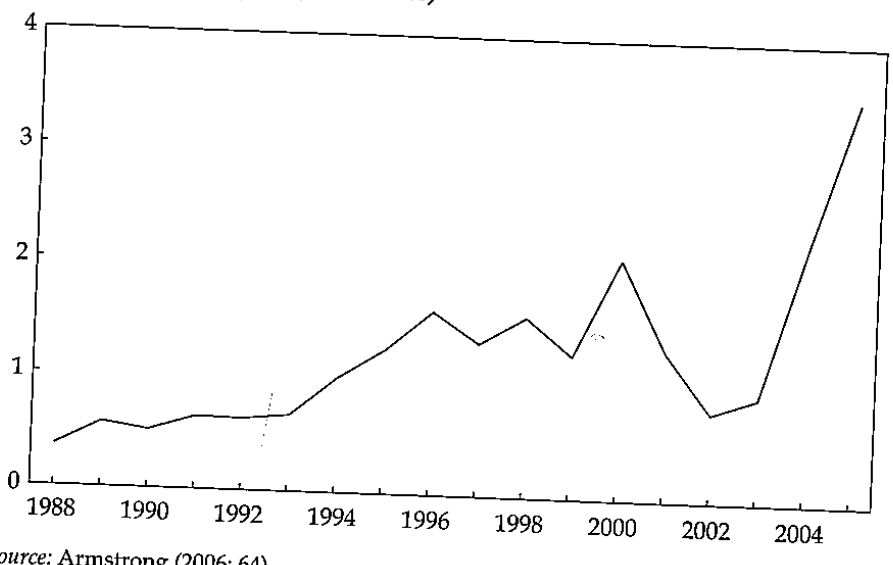

Source: Armstrong (2006: 64).

One of the most popular of East Java's Islamic gravesites, the tomb of Maulana Malik Ibrahim ${ }^{3}$ in the centre of Gresik near Surabaya, hosted $1,556,651$ visitors in 2005, up from 128,905 in 1988, a more than ten-fold increase. ${ }^{4}$ Annual visits to the tomb of Sunan Bonang ${ }^{5}$ in Tuban rose from 117,270 in 1988 to 618,047 in $2005^{6}$ and visits to the tomb of Sunan

3 Widely thought to be the earis

Malik Ibrahim the earliest of Java's proselytising Nine Saints, Maulana Vietnam.

4 The website of the district government of Gresik confirms this sharp upward trend, although its figures cover a shorter period. It reports that in the three years between 1999 and 2001, visits to theriod. It reports that in the three rose from 888,224 to 2003 , visits to the tomb of Maulana Malik Ibrahim [Potential and Opportunities for annum. See 'Potensi dan Peluang Investasi' potensi.doc>, accessed 7 June 2005 .

5 One of the Nine Saints and a son of

as Makdum Ibrahim) gathere of Sunan Ampel, Sunan Bonang (also known in the decades straddling 1500 ' 'Sunts' to Islam along the north coast of Java revered early disseminators of Islam in 's a title borne by many of the mos title, as well as a number of Islam in Java. Eight of the Nine Saints carry the Sendang Duwur, Sunan Geseng and Sunan Bejagung.

6 These figures, like Sunan Geseng and Sunan Bejagung.

These figures, like those cited by Armstrong and other sources, may underoffice but entrust numbers. Many pilgrims do not register in person at a site report that he the task to the leader of their group. The leader may simply When that he comes 'with a grouph-and-such a number sith When I visited the tomb of Sunan 
Drajat, ${ }^{7}$ located halfway between Tuban and Surabaya, rose from 26,381 in 1988 to 696,858 in 2005 . In the most dramatic increase, visits to the tomb of Ibrahim Asmorokondi ${ }^{8}$ just east of Tuban rose from 11,886 in 1988 to 467,896 in 2005, close to a forty-fold increase (Armstrong 2006: 65).

Pilgrimage sites in other parts of Java claim similar increases, though the figures are decidedly rubbery. When I visited the Great Mosque in Demak in 2000, custodial staff told me that in 1987 a total of 341,385 people had visited the mosque with its adjacent holy graves, but that by 2000 this had jumped to 606,918 people. A million visitors a year were claimed for the tomb of Sunan Gunung Jati ${ }^{9}$ in Cirebon in 1997. When I visited the site in 2002, staff assured me that visitor numbers were far above the 1997 figure.

\section{REASONS FOR VISITING LOCAL PILGRIMAGE SITES}

Why this relatively sudden spike in numbers? Clearly it is much more than a backward-looking, traditionalist response to rapid social change. Increasingly self-confident displays of Islamic identity and piety are a major factor. For many Muslims, whether followers of purist orthodoxy or those prepared to make accommodations with local beliefs and practices, visiting the tomb of a revered saint is an act of piety sanctioned by tradition and explicitly urged on Muslims by verses in the Qur'an as well as by the words of the Prophet recorded in Hadith.

The Qur'anic verse which has most often been cited to me in justification of pilgrimage is Al-Mā'idah verse 35, which reads:

that pilgrim numbers had been increasing at a rate of 10-20 per cent for the previous five years, culminating in a total of 526,268 visitors in 1996 . When I visited the tomb again in November 2003, staff assured me that visitor numbers had topped 1 million in 2002.

7 Tradition has it that Sunan Drajat-one of Java's Nine Saints - was a son of Sunan Ampel of Surabaya and the younger brother of Sunan Bonang. Known during his lifetime as Syarifuddin, he may have lived in the early $1500 \mathrm{~s}$. Other sources suggest that his original name was Ghosim and that he may have come to East Java from Cirebon some time in the early $1600 \mathrm{~s}$.

8 Ibrahim Asmorokondi is believed to have come from Samarkand in Central Asia some time in the 1500 s to preach Islam along the north coast of Java. Some believe that he is the same person as Maulana Malik Ibrahim.

9 Sunan Gunung Jati, one of Java's Nine Saints, played a key role in the establishment of Islamic states centred on Cirebon, Jakarta and Banten in the first half of the sixteenth century. He probably died around 1570.
O you who believe, honour God. Seek ways and means to come close to $\mathrm{Him}$

Do all you can in His cause, and if you do so you will to come close to Him

cession by the Prophet permitting believers to seek tawassul, that is, interbeliever. In order to accor by another figure 'close to God' on behalf of the God and the Prophet by way of pray, pilgrims say, believers may petition

On several occasin way of prayers to a local saint.

and well-authenticated pilgrims have also quoted to me the well-known Prophet is reported to Hadith from the Sahih Muslim in which the ful of death' 11 Pilorims said 'Visit graves, for that makes you minddominates almost totally in say that the Shafi'i school of law, which 'recommended' (mandub, indonesia, classifies the visiting of graves as nesia sometimes add conditions to this rough religious scholars in Indoregard to visits by women 12 to this recommendation, especially with

The steady rise in the number of pilgrims undertaking the hajj to the
Holy Land seems to be having a flow-ing Before and after performing the flow-on effect into local pilgrimage. the tombs of local saints as the hajj, many Indonesians make visits to a current cap on the nus part of the totality of the hajj experience. With $h a j j$, it is also possible that of Indonesians permitted to undertake the more than 30,000 du that some pilgrims who miss out-estimated at age as a substitute for the 'real hajj season-may make a local pilgrimmillions of Indonesians 'real thing'. Certainly for some of the many pilgrimage may be a kind of cannot afford to undertake the hajj, local Muslims may also

other than the hajj for the purpose vitality and respectability of travel a leading religious scholar (ulama) in invigorating faith. Said Aqil Siraj, sation, Nahdlatul Ucolar (ulama) in Indonesia's biggest Islamic organisation, Nahdlatul Ulama (NU), cites the great figures of the past Imam

own, made translations of Qur'anic verses in this chapter are the author's in English and Indonesian diverse renderings of the meanings of the verses

11 Sahih $M u s$ in, Book $4, N 0.21$

Sahih Muslim, Book 4, No. 2130. The full English text of the Hadith reads:

the grave of his mother and he wept and (may peace be upon him) visited and said: I sought permission from my Lord to others around him to tears, it was not granted to me, and I sought permissiog forgiveness for her but was granted to me. So visit the gouges formission to visit her grave and it (http://www.usc.edu/dethe graves, for that makes you mindful of death 004.smt.html).

12 Somec

they are menstruating and that they women should not visit holy graves while if they come into close proximity with become inappropriately 'emotional' debates surrounding women and pilgrimage, deceased. For a summary of the 
Bukhari, Ibn Khaldun, Imam Syafii and Ibn Battutah as examples of Muslim intellectuals whose travels were driven not only by curiosity about the world at large but also by their understanding of the Qur'an. This, Said Aqil says, 'impels people to constantly traverse the world in a quest for understanding of what is invisible to our eyes' (Said Aqil Siraj 2003).

Rising incomes and improvements in economic infrastructure are other important factors. Over the past three decades access to pilgrimage sites has become far easier. Roads, even to remote sites, are now sealed and often served by public transport. Many places now boast spacious parking areas, eateries and nearby hotel accommodation. In the early 1990s the beautiful holy place of Kahyangan in the hills south of Tirtomoyo in Central Java had no vehicular access. ${ }^{13}$ Pilgrims could only reach it after a two-kilometre walk along a rough, steep track. Long-stay visitors (apart from those who were fasting during their stay) had to bring their own food or return along the track to a nearby village to buy it. Today a sealed road runs right to the site's entrance, where there is also a parking area. Inside the compound there is a small eatery as well as a bathroom and simple overnight accommodation.

As part of this infrastructure improvement, some local governments are encouraging, or even directly investing in, the development of holy places as tourist attractions in the hope that the sites will attract sightseers or casual day-trippers as well as religiously motivated pilgrims.

\section{PILGRIMAGE SITES AS SOURCES OF REVENUE}

Today, an increasingly diverse array of revenue-raising practices and commercial interests are attaching themselves to local pilgrimage, feeding off the rising tide of visitors and at the same time investing in the system to further augment pilgrim numbers and boost turnover. Pilgrimage sites have always relied on pilgrims to fund their growth and their maintenance. ${ }^{14}$ Income from pilgrims provides a livelihood for site custodians, their families and surrounding communities. It also sustains the educational and charitable functions that all major sites have. There are three main ways by which pilgrims make direct contributions to the revenue and assets of a site: direct donations; promissory undertakings

13 The site commemorates a meeting between Panembahan Senopati and the spirit queen of the southern ocean. Senopati founded the central Javanese spirit queen of the southern ocean. Sen
state of Mataram some time in the 1580s.

14 But not entirely. In the past, and to some extent even today, holy places were given perdikan status; that is, they were protected by the state and freed from normal tax obligations. Today some sites are supported financially by government agencies such as the Archaeological Service in East Java. (nadar or kaul); and special endowments, whether land endowment (wakaf) or charitable cash endowments (zakat)

At most sites, it is proper etiquette for visitors

or to a supervising site custodian. gin, purpose of visit, nustodian. Visitors record their name, place of ori They also group and other details. cial column in the guest book. Rp 10,000 (about US\$1) 100,000 are not US 1 ) even for a group, though donations of up to Rp strategically along thual. At most sites there are also alms boxes placed ber itself. Beaus thoroughfares, in rest pavilions or in the burial chamthey are usually much ations made at alms boxes are more anonymous, common. Often much smaller-donations of $R p_{100} 1$ ( 1 cent) are very tion to path. At the tomb of stream past, sometimes physically blocking their yasa and other

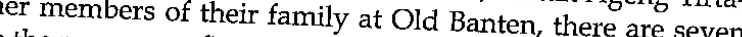
alms boxes in the narrow confines of the burial chamber, each manned by an attendant who will often gesture aggressively at his alms box as pilgrims pass by. At the tomb of Sunan Bonang in Tuban, attendants draw It is to the alms boxes by tapping on them loudly with sticks. saint in some fashion if a vow (nadar or kaul) to 'repay' a form of a cash donation if a wish is granted. The repayment may be in the form of repairs to thation to the site, but very often it is 'in kind' in the The burial chamber site or a gift of valuable appliances or decorations. Mount Kawi near at the tomb of Mbah Jugo and Imam Sujono ${ }^{15}$ on grandfather clost Java) is lined with more than a dozen least half a dozen glittering by recipients of the saints' largesse, and at the burial chamber (t)el railings donated by a grateful pilgrim Mount Mount Kawi tomb will arrange performances of shadow plays - including the special Chinese-style potehi shadow play-for pilgrims seeking to repay the generosity of the two saints. At the mausoleum of $\mathrm{Ki}$ Ageng Balak ${ }^{16}$ near Solo in Central Java, the custodial staff will arrange

$15 \mathrm{Mbah}$ Jugo and Imam Sujono are the main figures in a devotional cult cen tred on their twin graves in a mausoleum high on the slopestional cult cenThe site is famous for its power to bestow wealth slopes of Mount Kaw of the cult are obscure but many pilgrims believe that devotees. The origins Sujono fought with the messianic Prince believe that Mbah Jugo and Imam (1825-30).

$16 \mathrm{Ki}$ Age prince of the East a legendary figure believed by pilgrims to have been a help people in trouble with the law. 
for thanksgiving meals (slametan) to be served to all who happen to be present in the tomb's antechamber. So popular and so frequent are these meals that local villagers have complained about them, claiming that they attract freeloaders who eat better than they do. ${ }^{17}$

Some sites - though probably only a small minority of them - receive or manage wakaf and the collection of the Islamic tithe (zakat). The Prince Kuningan Foundation (Yayasan Pangeran Kuningan), for example, manages the tomb of Prince Kuningan in Jakarta and plays a principal role in the administration of a wakaf fund - the Al-Muqietu Land Endowment Fund (Wakaf Tunai Al-Muqietu). This allows people with limited financial means to buy cash shares in the fund. Eventually the proceeds of the fund will be used to buy land that will be donated to the Prince Kuningan Foundation as a collective wakaf endowment. ${ }^{18}$

Outside the burial chamber of most popular pilgrimage sites, and in some cases right by a saint's graveside, vendors sell the requisites of pilgrimage. These include flowers and flower petals (especially kenongo, kantil and mawar blossoms) that are scattered on a grave to honour the saint. Also sold are perfumed oil, incense, envelopes for cash donations, and bottles of water that are placed near a holy grave in order to be 'charged' with a saint's power. During a visit to the tomb of Ki Ageng Balak in 2004, I bought a small tube of (supposedly) raw opium in the vestibule of the mausoleum as an offering. It cost $R p 5,000$. The saint had a special liking for a pipe of opium, so the vendor told me.

In the vicinity of the busiest pilgrimage sites, paths and streets are filled with stalls and small shops selling souvenirs, books, clothes, food and drinks. Souvenirs may include locally made prayer beads, amulets, wall clocks with pious messages on them, portraits of saints, framed verses from the Qur'an, locally made ceramics, prayer mats and bottles of perfume. Religious books are on sale - the Qur'an, the Surat Yasin, ${ }^{19}$ books containing zikir chants and prayers in Arabic, books detailing the laws of Islam and the lives of saints. In many places, especially at the tombs of the Nine Saints, there are books giving the history of the site and the life story of the saint buried there. Cassette tapes and CDs of Islamic music and sermons also proliferate, not to mention colourful wall calendars focusing on the religious observances of the Islamic year.

17 '“Warga Asing" di Makam Balakan Disorot' ['Outsiders' under Scrutiny at the Balakan Tomb], Suara Merdeka, 21 May 2004.

18 'Wakaf Tunai Al-Muqietu Yayasan Pangeran Kuningan' [Cash Contributions to Al-Muqietu Land Endowment of the Prince Kuningan Foundation], <http://pangerankuninganfoundation.com/Wakaf.html>, accessed27 October 2007.

19 The 36th sura of the Qur'an, also written Ya Sin, often considered the most appropriate sura to read at someone's deathbed or graveside.
Invariably there are stalls selling clothes, not just explicitiy Islamic garments like scarves, jilbab head coverings, collarless shirts, black peci caps and white skullcaps, but also everyday attire, often secondhand, and footwear too. At restaurants and eateries pilgrims can usually buy local delicacies and other souvenir foods to take home to their families and neighbours. At the tomb of Sunan Drajat fake home to their families chase the local sticky-rice and Sunan Drajat, for example, they can purSunan bonang' the local stick-rice and coconut cakes known as wingko babat. At stration Place in the village of Bonang near Lasem they go home with pungent-smelling locally produced dried fish. At the Gunung Kawi site near Malang it is locally processed yams $(u b i)$ that are prized, and at the Great Mosque in Demak, star fruit (blimbing). At some sites, 'Islamic' foods such as dates and Middle Eastern sweetmeats are
on sale.

Many of the busier sites are surrounded by small hotels and homestay accommodation. At Gunung Kawi, for example, there are at least a dozen small hotels within cially if the main tomb. Especially if they arrive on their own or in small groups, as pilgrims approach many sites-Gunung Kawi, the Sam Po Kong complex in Semarang, the Imogiri royal tombs near Yogyakarta, the tomb of Sunan Gunung Jati in Cirebon-they will be accosted by local people claiming to be guides. Many pilgrimage sites also attract beggars, although officially begging is almost always frowned on. Notices around the tomb of Sunan Giri in Gresik and at Gunung Pring in Muntilan, for example, explicitly forbid begging, but there are nevertheless significant numbers of beggars along the approackes to the tombs - most of them women and beggars In a small number of holy places there are even significant numbers of prostitutes. Pangeran Samodro-a prince of the early Islamic state of Demak - is honoured as one of the first disseminators of Islam in the interior of Central Java. His tomb, and that of his lover and stepmother Nyai Ontrowulan, is at Gunung Kemuther Ombo Resures of the Kedung Ombo Reservoir north of Solo. The site has become controversial for its to engage in promiscuous sex.20

Improvements in transport infrastructure and steadily rising income pilgels have triggered a burgeoning services sector generically called pilgrimage tourism (wisata ziarah) or spiritual tourism (wisata spiritual). A majority of pilgrims now travel to pilgrimage sites by chartered bus.

20 Not all visitors to Gunung Kemukus engage in promiscuous sex, but a recent study describes the site as 'at a glance more resembling sex, but a recent prostitution complex', adding that the more resembling Jakarta's Kalijodo month are the principal source of the thousands of visitors who come every $\operatorname{man} 2006: 2$ ). 
Most of these trips are organised at village level by local clerics, officials or school teachers. Each pilgrim in a party pays a contribution towards the hire of the bus. Food is very often the responsibility of each individual, and in many instances pilgrims will sleep in the bus or (where it is allowed) in a mosque or rest pavilion at a pilgrimage site. Java and Madura do not have widely recognised standard pilgrimage routes, so there is considerable freedom in determining an itinerary. Pilgrimage tours can be quite strenuous. One privately organised group is reported to have set out by chartered bus from Mojokerto in East Java, taking in the tombs of Sunan Dugel (in Surabaya), Sunan Giri (Gresik), Sunan Drajat (Lamongan), Sunan Bonang (Tuban), Sunan Muria (near Kudus), Sunan Kudus (Kudus), Sunan Kalijaga (Demak) and Sunan Gunung Jati (Cirebon). The group then stopped in Jakarta where the pilgrims visited Taman Mini Indonesia Indah (a nationalistic theme park) and the giant Istiqlal Mosque before heading for the tomb of Sultan Hasanuddin in Banten. This was followed by visits to the holy tombs at Panjalu (near Ciamis), Pamijahan (south of Tasikmalaya), Gunung Pring (Muntilan) and Bayat (near Klaten). The tour culminated with prayers in the Great Mosque in Solo. ${ }^{21}$ More often, though, pilgrimage tours are shorter, extending only for as long, or as far, as the money lasts - which may not be very far at all.22

Increasingly, tour operators are offering pilgrimage packages specially tailored to the tastes of middle-class city dwellers, who expect their travel to be well organised, comfortable and even luxurious. Java Tours of Surabaya, for example, offers a 'Nine Saints of Islam Pilgrimage Tour' lasting six days and five nights. Travelling in an air-conditioned bus, pilgrims start out from Surabaya, staying overnight in Tuban, Kudus and Cirebon. The tour takes in each of the tombs of the Nine Saints, with a stop to shop for batik in Pekalongan. The tour includes accommodation in three-star hotels, all meals, entry tickets, baggage handling and the services of a guide. For groups of 15 or more, the cost is US $\$ 206$ per person twin share. Shorter tours and tours for smaller groups are also available.

Other companies offer variations on this itinerary. Linda Jaya of Surabaya, for example, offers what looks like a gruelling four-day tour starting from Surabaya, taking in all the Nine Saints tombs, and ending with visits to Borobudur and the royal palaces in Yogyakarta and Solo. It also includes an opportunity to go shopping in Solo. A number of companies

21 'PKL Keluhkan Parkir Bus Wisata' [Streetside Traders Complain about the Parking of Tourist Buses], Suara Merdeka, 1 February 2002.

22 'Menyatukan Jaringan Wisata Ziarah Walisongo' [Integrating the Nine Saints Pilgrimage Network], Suara Merdeka, 30 November 2004. offer pilgrimage tours to Java from Indonesia's outer islands and there are now even several Malaysian companies offering pilgrimage packages to Java for Malay Muslims. ${ }^{23}$

Decentralisation is placing pressure on district administrations to maximise local sources of revenue, the so-called regionally raised revSome now have box offices at their pilgrimage sites are being targeted. buy entry tickets, the rffices at their entrances. Visitors are required to the local government. There are now which may go largely, or entirely, to at, among others, the tombs of Sun government-operated ticket boxes (near Klaten) Gunung Srandil (near Kawi (near Malang), Ki Ageng Balak (near Solo), the burial

The district of the Great Mosque at Demak.

ment of an annual celebration Gresik has poured money into the developplace in the town celebration of Maulana Malik Ibrahim's birth. Taking fair (Gebyar Maulid) highlights to the saint's tomb, the Birthday Funespecially the drum highights the traditional Islamic arts of Gresiklocal goods. ${ }^{24} \mathrm{~A}$ similar strategn as beduk teter - and promotes the sale of government has invested hegy is in place in Demak, where the district linked to the holyvested heavily in revenue-generating celebrations Sunan Kalijaga at nearby Kadilangut Mosque and the mausoleum of the death of Dem Patah) and an annual founding king Raden Patah (Haul Akbar Raden held in the Javanese religious festival and procession (Grebeg Besar) ing of Sunan Kase month of Besar that climaxes with the ritual washproceeds can be considerable relics at the Kadilangu mausoleum. ${ }^{25}$ The Demak recives an emak receives an average of Rp 10 million (US $\$ 1,000)$ a day in receipts

and accommodation pack Kuala Lumpur, for example, offers a four-day trave tombs of the Nine Saints and ends with Lumpur that takes in seven of the renowned centre for teak and ends with a shopping trip to Jepara, Java's inclusive cost begins teak furniture and carved wooden artefacts. The allof $11-15$ pil begins from MR 957 (about US $\$ 324.00$ ) twin share for a See 15 pilgrims. More expensive options are available for smaller group Sub-05\%20-\%20DEc\%2007.m.m/wali_songo_5d4n_pilgrimage-Code-AK-

24 'Retribusi Ziarah $2007 . \mathrm{htm}>$

Pilgrims to Be Regularis Segera Ditertibkan' [Charges Levied on Holy Tomb

25 'Ribuan

Great Annual Commemoration Akbar Raden Patah' [Thousands Attend the ber 2003; 'Demak, Dongkrak PAD Raden Patah's Death], Kompas, 10 OctoTomb to Lift Locally Generated Revenului Makam Sunan' [Using the Saint's 'Generasi Wali Ally Generated Revenue], Suara Merdeka, 11 November 2001. God's Saints], Suara Mereka, 7 August 2005. [The Unbroken Generations of 
from the mausoleum of Sunan Kalijaga, and well over Rp 200 million (US\$20,000) from the Grebeg Besar festival (Turyanto 2007).

The intrusion of government revenue raising into the pilgrimage process has not been without its problems, however. For example, in 2001, when local government charges were introduced at the tomb of Maulana Malik Ibrahim, each party of pilgrims was hit with two different payments: Rp 10,000 levied by the Transport Infrastructure Service (Dinas Perhubungan) of the Gresik district government, and $\operatorname{Rp} 8,000$ levied by the village of Gapuro Sukolilo where the tomb is located. When the Gresik government proposed yet another charge of $\mathrm{Rp} 500$ per person for entry to the site, both pilgrims and site management protested. The negotiations that then took place resulted in a consolidation of payment arrangements and a discount for groups of 30 or more. ${ }^{26}$

\section{DEVOTION AS A COMMERCIAL TRANSACTION}

I have tried to paint a picture of the variety of commercial activities that characterise local pilgrimage in Java. The commercial facets of pilgrimage-indeed, of religious devotions in general-are sometimes seen as a corruption or diminution of the pilgrimage process. Ideally pilgrimage should be money-free and otherworldly, so it is often said. But for many pilgrims in Java, devotions at sacred places are in fact like commercial practices - the pilgrim enters into a transactional or contractual relationship with the supernatural, with a saint or with God.

In Islam, the supreme transaction involving a believer's person and possessions is the one in which God purchases the believer's soul, person and goods in exchange for eternal bliss. The Qur'an assures believers that God will abide by His promises - His contractual undertakings. This is made explicit, for example, in Fathir verses 29-30, which read:

Be assured, those who recite the Book of God, perform the prayer and spend what We have provided for them - whether it is spent secretly or in full view of the public - they make an investment that will return bountiful dividends. He will reward them generously and bestow His blessings upon them. (Q35:29-30)

In the same vein, As-Saff verses 10-12 show believers the way to a profitable transaction.

26 'Retribusi Ziarah Makam Segera Ditertibkan' [Charges Levied on Holy Tomb Pilgrims to be Regularised], Kompas, 18 April 2002; 'Dinilai Tidak Pantas, Memungut Retribusi dari Peziarah Makam' [It's Not Right, Asking Pilgrims to Pay an Entry Fee when They Visit Tombs], Kompas, 4 April 2002. O you who believe, let Me inform you of a trade that will save you from pain-
ful punishment. Believe in God and His messenger and devote your money
and your lives to the cause of God. This is the ber and your lives to the cause of God. This is the best deal for you, if you only gardens beneath which rivers flow forgive you your sins and admit you to eternity. That is indeed the suprow and to beautiful mansions in gardens of etrity. That is indeed the supreme triumph. (Q61:10-12)

In Java, devotions at pilgrimage sites are widely seen as contracts or transactions. Even the giving of donations is not an unselfish act above, nadar contracts are and divine merit for the giver. As mentioned pilgrim makes a vow to common. A nadar contract is one in which the giving meal, make a donation to a pilgrimart a charity, hold a thanksupon God's fulfilment of the ro a pilgrimage site - that is conditional actions are metaphors for devotional. In other words, commercial transies often explicitly recognise this. Take, forions. Qur'anic commentaron the word 'commerce' or 'this. Take, for example, this commentary (Q35:29). [The verse presents] a metaphor from commerce. [...] The believer must deny
himself the use of some of what God has provided, as a merchant puts aside
some of his wealth to invest as capital Only the Godly never fail or fluctuate; because Allah Only the Godly man's commerce will adds something to the return out of $H$ uarantees him the return, and even Islamic Researches, n.d.: 1,307-8, note 3,915).

Commerce at sacred sites, then, is an embodiment of the transactional or corruption of devotion, but rather. It is not an intrusion, diminution manifestation of the inter, but rather an integral part of it-a material

\section{PERSONAL FAVOURS FROM POWERFUL BEINGS}

There is another important side to the commercial character of sacred sites, a variation perhaps of that just described. Many pilgrims go to sonal favour that has a supernaturan ngalap berkah, that is, access a performs-success in an examination findin. This favour may take many promotion at work, recovery from, finding a good wife or husband, the desire for wealth probabily predlness. But of all the favours sought, money' at such sites lies a dy predominates. Behind the quest for 'easy can never wholly be a product of individuniction that personal wealth always, at least in part a quct of individual enterprise and action, but is the infinite natural abundance of accessing the powerful beings and all blessings, including the 'blessing' supernatural. For some pilgrims 
cial success, come from God, and God's power is accessed by way of the intermediaries at certain sites. It is also possible that the allure of sacred sites as sources of commercial success derives in part from a lack of familiarity with the workings of cash-based commerce. For some, the huge wealth that some individuals acquire apparently 'effortlessly' can only be supernatural in origin. ${ }^{27}$

It is true that many Muslims look on the practice of ngalap berkah with suspicion, even horror. Some regard it as idolatrous (syirik). The purpose of religious devotions is to praise God, or simply to obey His laws and commandments, or, for a few, to seek mystical union with God. But to approach God or His saints with the intention of enriching oneself is seen, at best, as irrational and backward, and at worst idolatrous and a violation of God's laws.

But many Indonesian Muslims disagree. During a visit a few years ago to Goa Langse, a holy cave near Parangtritis on the south coast of Java, I asked one pilgrim whether, according to Islam, it was idolatrous to ask God or God's saints for material blessings. With some vigour he told me that all good things come from God, and the truly devout Muslim must acknowledge this. Not to acknowledge it - to claim that the material good things of life come from oneself and not from God - is to act idolatrously and give oneself God-like powers. Therefore, it is only proper that the devout Muslim ask God-or one of God's saints-for whatever it is that he or she needs or wants. It would be arrogant, even idolatrous, not to do so.

Behind the practice of ngalap berkah lies a theology that I will call the theology of distance and proximity. With the exception of certain Sufis, most Muslims would agree that there is a qualitative contrast or 'distance' between God and believer in line with the orthodox notion that God and humankind are utterly different. That the two are different in essence is widely given a metaphorical cloak in which the notion of difference is translated into the notion of distance. But this distance is not unbridgeable. People can get close to God, or to put it another way, there are degrees of proximity to God.

27 Several observers have noted the belief among Javanese traders that ascetic practices of one kind or another are just as or more essential to business success than the conventional basics of business practice and acumen. Brenner (1998: 192) notes that, traditionally, batik merchants in Laweyan (Solo) regarded self-denial and ascetic austerities (laku) as the main keys to business success. The same point is made by Suwardi Endraswara (2006: 290), who also lists the following pilgrimage sites as important to Javanese businesspeople: Gunung Kemukus, Gunung Srandil, Gunung Kawi, Makam Sewu and Parangtritis (Suwardi 2006: 289).
In most parts of the world and in most religious traditions, God is perceived as being closer to humankind in certain places and at certain close to God. These certain individuals who have succeeded in getting be called 'auspicious maces may be called 'holy places'; the times may beloved of God - in Java ; and the people may be called saints or the close to God, then pilgrim's effort to cious time, to petition God or her to a holy place, especially at an auspithrough tawassul - the mediation, or to get as close as possible to God one can get to God, the mato closer ing the benefit of material the source of all benefits, includ-

The twin ideas of transaction and proximity go a long way towards
explaining the integration of nomenon in Java, and make it commerce into the local pilgrimage phenarrowly romanticise make it possible - in fact essential - to discard the diation of commercial worldliness.

\section{A PROTECTION AGAINST RADICALISM?}

There is, I believe, yet another important facet to the connection between money and sacred places. The increasing commercialisation of pilgrimvisit them against radicalisation pilgrimage sites and the Muslims who Wahhabist against tombs and saint veneration, pits itself with particular viciousness ant of extremism has recently, Malaysia, saint veneration most nobly Saudi Arabia and, more largely been wiped out. ${ }^{28}$ Amrozi and pilgrimage to holy tombs has are reputed to have vandalised gravesites in Lothers, the 'Bali bombers', Salafi practices in Afghanistan 29 gravesites in Lamongan after adopting

But where local pilgrimage and

ponents in the economy - a source of inceration are significant comotherwise be garner support for the kind of a living-it becomes more difficult to

Muhammad bin Abdul Wahhab (1703-92) and his followers were instrumen-
tal in destroying certain gravesites in Arabia and in tion. His influence is felt gravesites in Arabia and in opposing saint venerahave been destroyed in today in Malaysia, where a number of holy

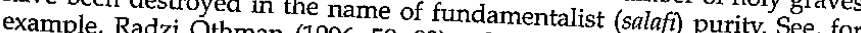
revere, Radzi Othman (1996: 59, 83), who reports on he desty. See, for revered gravesites in the state of Malaka and deports on the destruction of spread of what he sees as a 'purer' variant and describes with approval the 29 I am grateful to Dr Greg Fealy for this inf of Islam in Malaysia. 
source of income. This does not mean, of course, that pilgrimage to holy tombs is ipso facto a protection against radicalism. In some parts of the Islamic world-even in Java-some holy places have been incubators of rebellion or radicalism. Nevertheless, on the whole there is reason to believe that the commercialisation of holy sites is a moderating factor in the contentious competition between radical and liberal in Indonesian Islam. Even extreme 'modernists' who have been scathing about local pilgrimage and saint veneration, often seeing it as 'superstition' or backwardness and (with its visions and miracles) irrational, may be placated if sacred sites are seen as sources of business enterprise-or at least as acceptably exotic 'tourist attractions'.

\section{THROWING MONEY AT THE HOLY DOOR}

In the humid mid-morning warmth, pilgrims are sitting in packed ranks on the floor before the Prostration Door at the tomb of Sunan Gunung Jati on the outskirts of Cirebon, West Java. The door is massive. It is made of wood darkened by incense smoke and the passage of time since it was built perhaps as long as 400 years ago. It is set in a high, yellowishwhite plaster wall inlaid with ancient tiles, ceramic dishes and other decorations. To the left and right of the door stand large porcelain jars from China - probably also hundreds of years old - and on the two steps in front of the door stand iron incense burners. Their heads reverently bowed, the pilgrims intone the tahlil chant: La illaha ila'lah, 'There is no god but God'.

The gentle rhythms of the tahlil chant swell and die to the intermittent accompaniment of metallic jingling. Coins are being thrown at the door. They bounce off and fall ringing to the tiled floor. Several women rise from the floor and approach the door. One produces a fistful of banknotes and presses several of them into the crevices in the door. She wipes the remaining notes across the face of the door and returns them to her sash. The money that she leaves behind in the door is her side of a transaction - a contract - that is both devotional and 'commercial'. And the money that she takes away has been imbued with the special power that comes from the proximity of the door - and of the saint who lies buried behind it - to the infinite power of God and the supernatural.

As the pilgrims finish their devotions and leave the chamber, tomb orderlies-young men wearing ankle-length batik sarongs, neat white jackets and batik headcloths - remove the notes and sweep up the coins, throwing the money into a brass bowl that is already overflowing with cash. Their livelihoods, and those of the surrounding community, not to mention the continuing vigour of the holy place itself, get the cash injection that guarantees their continuity.

\section{REFERENCES} Armstrong, David (2006), Tingkat Kunjungan Wisatawan ke Situs Purbakala di
Jawa Timur: Data Selama 18 Tahun 1988-2005 [Visitor Numbers at Archaeo-
logical Sites in East Java: Figures over the 18 Years from gram ACICIS, Fakultas Sosial dan Ir the 18 Years from 1988 to 2005], ProMalang, Malang.

Brenner, Suzanne À

Modernity in Java, Princeton University Press, Prinesire: Women, Wealth and de Guzman, Orlando (2006), Apakah Arsity Press, Princeton NJ.

Mitos Pangeran Samodro di Gunung Kemukungan Antara G30S dan Munculnya Attempted Coup of 30 September Kemukus? [Is There a Link between the Samodro Myth at Mount Kemukus?] 1965 and the Appearance of the Prince try Indonesian Study and Fakultas Ilmu Muhammadiyah Malang, Malang. Presidency of the Islamian, Malang.

English Translation of the Meanings and Commentaryidance (n.d.), Holy Qur-an: Printing Complex, Madinah.

eri Perlis dan Hubung Kaitnya dengan Man Pembaruan Islam: Satu Kajian di NegMovement in Perlis and Its Link into Malaysia [A Study of the Islamic Reform Pinang.

sainang.

of Religion in Tourism], Republika, 12 September
ofisisata' [The Revitalisation Sulaim, Syaikh Amru Abdul, Republika, 12 September.

Practice of Pilgrimage to Graves for Women] , Adab Ziarah Kubur Bagi Wanita [The Suwardi Endraswara (2006), Mistik Kejawen: Sink Pustaka Al-Kautsar, Jakarta. dalam Budaya Spiritual Jawa [Javanese Mysticism: Syme, Simbolisme dan Sufisme Sufism in the Spiritual Cualturanese Mysticism: Syncretism, Symbolism and

Turyanto (2007), 'Demak, Si Miskin Java], revised edition, Narasi, Yogyakarta. ous], dated 29 June 2007, available at <htt: / turyan' [Demak, Poor but Gener06_01_archive.html>, accessed 10 October 2007. 


\section{CONTRIBUTORS}

Maria Ulfah Anshor: General Chair of Fatayat Nahdlatul Ulama (Fatayat NU); Member of Parliament for the National Awakening Party (PKB)

Muhammad Syafii Antonio: Member of the Expert Committee of Bank Indonesia and the Sharia Advisory Council, Central Bank of Malaysia; Member of the Board of Directors and Sharia Advisor, Bank Export Indonesia, Bank Syariah Mandiri, Bank Syariah Mega, Takaful Insurance and Permodalan Nasional Madani

Robin Bush: Deputy Country Representative for Indonesia, The Asia Foundation, Jakarta.

Greg Fealy: Fellow and Senior Lecturer in Southeast Asian Politics, Research School of Pacific and Asian Studies and Faculty of Asian Studies, Australian National University, Canberra

James B. Hoesterey: PhD Candidate, Department of Anthropology, University of Wisconsin-Madison, Madison

Nadirsyah Hosen: Lecturer, Faculty of Law, University of Wollongong, Wollongong

Julia Day Howell: Associate Professor in Asian Studies, Department of International Business and Asian Studies (IBAS), Griffith University, Brisbane; Deputy Director, Griffith Asia Institute, Griffith University, Brisbane.

Umar Juoro: Commissioner, Bank Internasional Indonesia (BII), Jakarta; Chair, Center for Information and Development Studies (CIDES), Jakarta; Senior Fellow, Habibie Center, Jakarta

Julian Millie: Australian Research Council (ARC) Post-doctoral Fellow, School of Political and Social Inquiry, Faculty of Arts, Monash University, Melbourne 
George Quinn: Head and Senior Lecturer, Southeast Asia Centre, Faculty of Asian Studies, College of Asia and the Pacific, Australian National University, Canberra

M.C. Ricklefs: Professor, Department of History, Faculty of Arts and Social Sciences, National University of Singapore, Singapore; Adjunct Professor, Research School of Pacific and Asian Studies, Australian National University, Canberra; Honorary Professor, Monash University, Melbourne

Minako Sakai: Senior Lecturer, School of Humanities and Social Sciences, University of New South Wales, Australian Defence Force Academy (ADFA) campus, Canberra

Ken Ward: Consultant on Indonesian Politics and Terrorism, Canberra Sally White: Visiting Fellow, Division of Pacific and Asian History, Research School of Pacific and Asian Studies, Australian National University, Canberra

Ian Douglas Wilson: Post-doctoral Research Fellow, Asia Research Centre, Murdoch University, Perth 